\title{
Pragmatik i ordbogen: Hvordan kan fokusadverbiet godt beskrives i en dansk-tysk ordbog?
}

\section{BJARNE ØRSNES}

\begin{abstract}
Eksisterende nyere mono- og bilingvale ordbøger giver ikke nogen tilfredsstillende beskrivelse af fokusadverbiet godt på trods af at der findes grundige analyser af denne brug af godt. Enten optræder godt ikke med en selvstændig leksikalsk indgang, men kun i eksempler for de verber det typisk forekommer sammen med, eller også har det et selvstændigt opslag, men adverbiets kernebetydning bliver ikke helt klar. Og det er svært at beskrive godt. Det har en pragmatisk betydning, det er i reglen bundet til bestemte verber og opfører sig derfor mest af alt som del af en kollokation og endelig lader det til at mangle ækvivalenter i målsprog som engelsk og tysk. Artiklen giver et forslag til en leksikalsk beskrivelse af fokusadverbiet godt i en bilingval ordbog (dansk-tysk) på baggrund af en semantisk-pragmatisk og syntaktisk analyse der udvider de eksisterende analyser af godt, og på baggrund af en undersøgelse af hvordan godt gengives på tysk i et korpus med parallelle danske og tyske tekster.
\end{abstract}

EMNEORD: fokusadverbier, polaritetsfokus, kollokationer, leksikografi, parallelle korpora

\section{INDLEDNING}

Ord kan være vanskelige at beskrive i ordbøger af mange grunde. De kan have mere eller mindre 'abstrakte' eller pragmatiske betydninger. De kan have særlige begrænsninger som gør at bestemte betydninger typisk - men ikke kun - opstår i kombination med bestemte andre ord og i bestemte syntaktiske omgivelser. De kan have funktioner som ikke i samme grad udtrykkes på et givet målsprog. Og nogle ord har det hele på én gang.

Et eksempel på et sådant problematisk ord er det danske godt der som selvstændigt adverbielt sætningsled kan bruges som en (i reglen 
positiv) beskrivelse af hvordan en handling bliver udført som i (1), og i en mere 'abstrakt' og subjektiv betydning som i (2) til at understrege at noget rent faktisk er tilfældet (måske imod forventning) (Jensen 1997, 2000: 141-142, 2007, 2009). ${ }^{1}$

(1) Jeg har last kontrakten godt. (Jeg har læst den grundigt.)

(2) Jeg har godt last kontrakten. (Jeg har faktisk læst den.)

Man kan her vælge at sige at der findes ét adverbium godt der kan bruges på to forskellige måder: til beskrivelse af måden og som subjektiv vurdering af et udsagns gyldighed. Man kan også vælge at sige at der findes to forskellige adverbier godt: et mådesadverbium som er knyttet til adjektivet god, og et 'subjektivt' adverbium godt (som jeg senere vil udnævne til fokusadverbium). Jeg hælder mest til den sidste løsning ud fra den betragtning at det subjektive eller 'abstrakte' godt i mange henseender er helt forskelligt fra adjektivet god og dermed mådesadverbiet. Det afgørende er dog for fremstillingen her at der er tale om to forskellige betydninger. Når jeg i det følgende taler om godt, mener jeg godt $\mathrm{i}$ den 'abstrakte' brug, medmindre det er klart ud fra sammenhængen at der er tale om ordet godt eller godt som mådesadverbium.

Og der er en yderligere komplikation ved dette godt: Den 'abstrakte' betydning som det primært skal handle om her, forekommer fortrinsvist sammen med bestemte verber, nemlig ville, kunne, måtte, turde og sanse- og erfaringsverber som fortalle, se, lase og hore.

Der findes grundige analyser af den 'abstrakte' brug af godt som adverbium (Jensen 1997, 2000, 2007, 2009; Hansen og Heltoft 2011), og også Ordbog over det danske Sprog (ODS) giver en selvstændig beskrivelse af godt i den 'abstrakte' betydning og forsøger at identificere en egentlig kernebetydning. Alligevel synes disse tidligere behandlinger af godt ikke at have fundet vej til de moderne leksikografiske beskrivelser. Og det er i sandhed vanskeligt at beskrive godt. Skal godt nu overhovedet optræde som en selvstændig leksikalsk størrelse, eller skal

1 Faktisk kan ordformen godt optræde i mange sammenhænge: Godt kan forekomme som interjektion (Godt, lad os komme i gang), i adjektiviske funktioner (et godt tilbud/ jeg finder tilbuddet godt) og $i$ adverbielle funktioner, enten inden for en substantivgruppe (godt to år) eller som selvstændigt sætningsled (jeg kender godt Peter/jeg kender Peter godt). 
det optræde som en kollokationel størrelse sammen med de tilhørende verber ville, kunne etc.? Og hvis det er en selvstændig størrelse: Skal godt i den 'abstrakte' betydning være en underbetydning af et adverbium godt afledt af god, eller skal det - som nævnt ovenfor - være et selvstændigt adverbium? Og så det afgørende spørgsmål: Hvad betyder den her 'abstrakte' brug af godt præcist, og - når der er tale om en bilingval ordbog - hvordan kan den betydning gengives på et andet sprog?

Gyldendals Dansk-Tysk Ordbog fra 2007 er et eksempel på at den 'abstrakte' anvendelse af godt er svær få hold på. Så vidt jeg kan se, forekommer godt som i (2) ovenfor faktisk kun to steder, nemlig under vide i eksemplet jeg ved det godt og under kunne i eksemplet det kan godt vare at ... . Og oversættelsen er i første tilfælde at det ikke oversættes. På tysk hedder det så ich weiß (es), mens det i andet tilfælde oversættes med schon: es mag / kann schon sein, dass ... Spørgsmålet er så hvad man som bruger af denne ordbog gør når man sidder med et eksempel som (2), og spørgsmålet er også om dette godt - når nu det ikke altid behøver at blive oversat - virkelig er redundant på dansk, eller om det har en betydning som det kan være relevant at gengive på tysk.

Målet med denne artikel er primært at give et forslag til hvordan godt i den 'abstrakte' betydning kan beskrives i en bilingval ordbog, dansk-tysk. Jeg vil foreslå en analyse af godt som egentlig er en udvidet syntese af analyserne i Jensen (2009) og Hansen og Heltoft (2011). Jeg vil foreslå at godt er et fokus-adverbium, specialiseret til at fokusere polaritet, altså til at understrege om noget er tilfældet, eller netop ikke er tilfældet. Godt er så specielt ved at det kun bruges til at fokusere positiv polaritet (nemlig at noget er tilfældet). Samtidig vil jeg undersøge hvordan godt kan oversættes til tysk, og hvornår - altså i hvilke kontekster. Det gør jeg ved at undersøge danske og tyske paralleltekster. Denne undersøgelse munder ud i et forslag til hvordan godt som fokusadverbium kan beskrives i en bilingval dansk-tysk ordbog af samme omfang som Gyldendals Dansk-Tysk Ordbog.

\section{GODTSOM FOKUSADVERBIUM}

Den 'abstrakte' betydning af godt som i (2) findes når godt optræder i en bestemt position i sætningen. Hvis godt står på mådesadverbialets plads (efter hovedverbet) som i (3), får vi læsningen hvor godt beskriver 
hovedverbet yderligere, og hvis godt står på neksusadverbialets plads (før hovedverbet) som i (4), får vi den 'abstrakte', subjektive læsning (Jensen 1997, 2000: 141-142).

(3) fordi jeg kender Louise godt. (Vi hører noget om intensiteten af bekendtskabet.)

(4) fordi jeg godt kender Louise. (Vi hører at afsenderen faktisk kender Louise, men ikke hvor godt.)

Præcis det samme gør sig gældende ved et adverbium som nok som i (5) og (6). På pladsen for mådesadverbialer får vi læsningen tilstrakkeeligt, og på pladsen for neksusadverbialer får vi læsningen sandsynligvis.

(5) Han har spist nok. (tilstrækkeligt)

(6) Han har nok spist. (sandsynligvis)

Det er således karakteristisk at jo længere til venstre i sætningen adverbiet står, jo mere subjektiv bliver betydningen: Det kommer til at handle om afsenderens vurdering af udsagnets gyldighed og mindre om kvaliteten af den handling der bliver udført. I sætninger med ledsætningsordstilling ('det neutrale mønster' i Hansen og Heltoft 2011) som i (7) står det 'abstrakte' godt (ligesom sætningsadverbialer) foran det finitte verbum og dermed også foran eventuelle infinitte verber. ${ }^{2}$ I sætninger med hovedsætningsordstilling ('det deklarative mønster' i Hansen og Heltoft 2011) som i (8) står det 'abstrakte' godt foran eventuelle infinitte verber.

(7) a. Jeg slàr det ik.ke op eftersom jeg godt ved det.

b. * Jeg slair det ikke op eftersom jeg ved det godt.

(8) a. Jeg har godt bort det.

b. * Jeg har hort det godt.

Man kan faktisk - under lidt ekstreme betingelser - komme ud for at man ikke kan se ud fra positionen om et godt er brugt i den 'abstrakte' betydning eller til angivelse af måden. Et eksempel er (9a), hvor ho-

2 Hansen (1970: 127) omtaler disse adverbialer som 'faste delkædeadverbialer'. 
vedverbet i en sætning med hovedsætningsordstilling er finit, og hvor objektet er et lille tryksvagt pronomen. Her er man henvist til konteksten. I samme øjeblik objektet er et substantiv som i (9b), er der ikke nogen problemer længere.

(9) a. Jeg kender bende godt. (Jeg kender hende faktisk vs. vi er nære bekendte.)

b. Jeg kender godt direktoren vs. Jeg kender direktoren godt.

I modsætning til sætningsadverbier kan det 'abstrakte' godt dog ikke stå på førstepladsen foran det finitte verbum i sætninger med hovedsætningsordstilling (10). Her opfører godt sig ligesom negationen ikke (11), modalpartikler som jo (12) og adverbier som kun (13), der traditionelt kategoriseres som fokuspartikler eller -adverbier (König 1991, Hansen og Heltoft 2011).

(10) * Godt kender jeg hende. ${ }^{3}$

(11) * Ikke kender jeg hende.

(12) * Jo kender jeg hende.

(13) * Kun kender jeg hende. (i læsningen: jeg kender hende kun) ${ }^{4}$

Til gengæld kan godt (og kun) forekomme i infinitivkonstruktioner, (14) og (15) - i modsætning til sætningsadverbier (16) og modalpartikler (17).

(14) Han er begyndt godt at ville putte lidt, (... $)^{5}$

(15) Han er begyndt kun at ville putte lidt

3 Adverbiet vel kan forekomme forstærkende i fundamentfeltet, men Christensen (2012: 14) foreslår at veli denne position er brugt "bedyrende" i højere grad end som udtryk for epistemisk sikkerhed. En bedyrende brug vil dog nok forekomme i præcis de samme kontekster som godt, nemlig når man forventer modtageren har en anden opfattelse

(1) Vel kender jeg ham.

4 Eksempel (13) er muligt i en læsning hvor kun indskrænker et tidligere udsagn i betydningen: Der er bare det ved det at ... / dog med den forskel at ... Kun er altså her brugt som et adverbium der skaber forbindelse bagud $\mathrm{i}$ teksten, ligesom adverbier som derfor, alligevel og hermed.

5 https://www.baby.dk/debat/231803pi1/boern-13-aar/til-jer-med-meget-aktive-boern.aspx, tilgået 22/12 2017. Jeg bruger typisk autentiske eksempler til at illustrere mine egne intuitioner i tilfælde hvor der ikke er tale om forhold som i forvejen er velbeskrevne. 
(16) * Han er begyndt heldigvis at ville putte lidt

(17) * Han er begyndt jo at ville putte lidt

Så godt opfører sig præcis som fokusadverbier som kun. Også Hansen og Heltoft (2011) gør godt til et fokusadverbium (om end de taler om 'fokuspartikler' som en undergruppe af adverbier, s. 1073), mens Jensen (1997) taler om en polær markør, og Jensen (2009) taler om en affirmativ partikel, hvilket dog ikke indfanger parallellen til fokusadverbierne. Karakteristikken af godt som en negation med kompleks semantik i Jensen (2007) passer bedre med godts syntaktiske egenskaber, men der er stadig væsentlige forskelle mellem godt og ikke, som jeg vender tilbage til nedenfor.

Også på andre måder opfører godt sig som fokusadverbiet kun. Jensen (2009: 66-67) siger at godt er bundet til neksusadverbialets plads (mellem subjektet og eventuelle infinitte verber), og at godt slet ikke er mobilt, men det passer nu ikke helt. Ligesom andre fokusadverbier kan godt anteponeres. Det vil sige at godt $\mathrm{i}$ forbindelse med epistemiske verber som tro, mene og synes kan optræde i matrixkonstruktionen sammen med det epistemiske verbum selvom det betydningsmæssigt hører hjemme i ledsætningen (Hansen 2000; Boye 2007; Hansen og Heltoft 2011: 796, som taler om 'adverbialknude'). Dette fænomen kaldes også 'neg-raising' i den generative tradition eller 'mobil negation' fordi det ofte ses ved negationen som $\mathrm{i}$ (18).

(18) Jeg tror ikek jeg kan nå det. $\rightarrow$ Jeg tror jeg ikeke kan nå det.

(19) Jeg tror godt jeg kan nå det. $\rightarrow$ Jeg tror jeg godt kan nå det.

(20) Jeg tror kun jeg har to ol. $\rightarrow \quad$ Jeg tror jeg kun har to ol.

Netop fordi godt ikke uden videre kan kombineres med alle verber, kan man let vise at et godt i kombination med et epistemisk verbum som mene eller tro egentlig hører betydningsmæssigt hjemme i ledsætningen. Hvis ledsætningen indeholder et verbum der ikke så let kan kombineres med godt, bliver hele sætningen tvivlsom. I (21) kan pjakkee ikke kombineres med godt, og dermed er hele sætningen uheldig. I eksempel (22) er der derimod ingen problemer fordi forstå sagtens kan kombineres med godt. 
(21) ?? Jeg tror godt han pjckeker. $\rightarrow$ ?? Jeg tror han godt pjakkeer.

(22) Jeg tror godt han forstär det. $\rightarrow$ Jeg tror han godt forstair det.

Fokusadverbiet godt er ligesom kun også mobilt på en anden måde. I ledsætninger med hvis eller når kan godt rykkes frem så det optræder umiddelbart efter den underordnende konjunktion. Her opfører fokusadverbierne godt og kun sig ligesom negationen ikke (Pedersen 2009; Ørsnes 2012).

(23) (og det tyder det på, når godt du kan hente pdf filer) ${ }^{6}$

(24) (...), når kun du kan hente pdf filer

(25) (...), når ikke du kan bente pdf filer

Godt har med andre ord en del til fælles med negationen: De står begge i neksusfeltet, de kan ikke stå i fundamentfeltet, og de kan begge rykkes frem i sætningen med epistemiske verber og visse underordnende konjunktioner. Jensen (2009: 71) går faktisk så vidt som til at sige at godt er det positive modstykke til negation ikke (og Sudhoff 2012: 122 siger det samme for det nederlandske wel. Men der er nu en meget væsentlig forskel på godt og ikke. Ikke er i stand til at vende en sætnings polaritet (typisk fra positiv til negativ), mens godt ikke har nogen som helst indflydelse på en sætnings polaritet (som Jensen 1997 også skriver). En sætning er positiv både med og uden godt, jf. (26a) og (26b). Godt forstærker en betydning der er i forvejen - til forskel fra negationen (der er andre forskelle som jeg vender tilbage til nedenfor).

(26) a. Jeg ved det.

b. Jeg ved det godt.

Men der er noget specielt med godt og negationen. Godt kan kun forekomme i positive sætninger, altså i sætninger uden ikke og uden negerede ord som ingenting og aldrig.

6 Eksempel fra: https://www.computerworld.dk/eksperten/spm/423393, tilgået 11/6 2017. Jeg har dog ikke undersøgt hvor almindeligt forekommende konstruktioner med fremflyttet godt er. Umiddelbart gæetter jeg på at det primært tilhører et talesprogsregister. 
(27) * Han forstår godt ingenting. ${ }^{7}$

(28) * Han tor aldrig godt tage en chance.

Hvis godt en sjælden gang forekommer sammen med negation (inden for negationens virkefelt), forstås det som et (skjult) citat - altså som en irriteret tilbagevisning af noget en anden har påstået som i (29). ${ }^{8}$

(29) Jeg vidste det ikke godt. (nogen har sagt: Det vidste du godt)

På den måde er godt et positivt polaritetsudtryk: Et udtryk der kun kan forekomme i positive sætninger, som adverbiet allerede.

(30) a. Hun er ber allerede.

b. * Hun er her ikee allerede.

Spørgsmålet er så om godt som fokusadverbium (i den 'abstrakte' betydning) kan modificeres af andre adverbier. Som modifikatorer for godt forekommer bl.a. så, (kun) alt for, meget, temmelig, udmarket og valdig. Her er det igen vigtigt at skelne mellem godt som mådesadverbium og godt som fokusadverbium. Udmarket synes at være forbeholdt læsningen som fokusadverbium. Udmarket kan ikke så godt forekomme ved det efterstillede godt - altså hvor godt optræder som mådesadverbium.

(31) a. fordi jeg udmarket godt kender ham.

b. ??/* fordi jeg kender ham udmarket godt.

De andre former for modifikation som valdig, så, alt for, meget og temmelig kan forekomme ved mådesadverbiet godt, men det er svært at sige om

7 Godt kan forekomme sammen med ingenting som mådesadverbium.

(2) Han forstair ingenting godt.

8 Godt kan faktisk forekomme sammen med ikke når ikke bruges i et såkaldt 'biased question' (Romero og Han 2004), hvor afsenderen altså går ud fra at noget er sandt og gerne vil have det bekræftet (3), eller hvor et tilsyneladende spørgsmål er ment som et påbud som i (4).

(3) Kender du det ikkee godt? (http:/ / helseværkstedet.dk/de-særligt-sensitive, tilgået 11/1 2018)

(4) Vil du ikeke godt bolde op?

9 Jeg betragter lige så godt som som en fast vending eller indskud. Det adskiller sig fra godt ved at kunne efterstilles.

(5) fordi han ved det lige så godt som jeg. 
de også kan modificere det 'abstrakte' godt. Faktisk virker det som om det afhænger af det tilhørende verbum.

(32) a. ?? fordi jeg temmelig godt kender ham.

b. fordi jeg temmelig godt kan lidt ost.

c. ? fordi jeg kun alt for godt kender ham.

d. fordi jeg kun alt for godt kean lide ost.

e. * fordi jeg alt for godt vil takke formanden for hans indsats.

f. ?? fordi jeg kun alt for godt har hort det.

Forholdene omkring modifikation af godt er med andre ord komplicerede, og i det følgende vil jeg derfor se bort fra eksempler med modifikation.

Alt i alt opfører godt sig syntaktisk som et fokusadverbium ligesom kun. Det adskiller sig dog fra kun ved at være begrænset til at lægge sig til hele sætninger (kun kan f.eks. også lægge sig til substantivsyntagmer: Kun medlemmer deltog $i$ modet) og ved kun at forekomme i positive sætninger.

\section{GODT SOM FOKUS PÅ POSITIV POLARITET}

Som nævnt er det mest påfaldende (og komplicerede) ved 'abstrakt' godt at adverbiet ikke bidrager med nogen egentlig deskriptiv semantik. I både (33a) og (33b) fortæller afsenderen at hun kender Peter.

(33) a. Jeg kender Peter.

b. Jeg kender godt Peter.

Merværdien ligger $\mathrm{i}$ at godt forstærker en betydning der er i forvejen, nemlig den positive polaritet (Jensen 1997: 156). Hvis man skal parafrasere forskellen mellem (33a) og (33b), kunne det være:

- (33a): Det er tilfældet at jeg kender Peter

- $\quad$ (33b): Det ER altså tilfældet at jeg kender Peter (jeg kender ham i forvejen)

Både (33a) og (33b) fortæller noget sandt om verden, men i (33b) bli- 
ver det ekstra understreget at det er sandt. Godt er med andre ord et leksikalsk middel til at udtrykke (positivt) polaritetsfokus (også kaldet verumfokus i den tyske tradition (Höhle 1992) efter det latinske ord for 'sandt' eller 'virkeligt'). ${ }^{10}$ Ved negativt polaritetsfokus bruger man derimod typisk prosodisk fremhævelse af negationen.

(34) Jeg kender ham IKKE. (Kan du så forstå det ...)

Godt forekommer da også typisk i sætninger hvor polaritet (om noget gælder eller ikke gælder) spiller en rolle. Godt kan forekomme i fremsættende sætninger (som er sande eller falske), (35), og i ja/ nej-spørgsmål, (36), hvor man netop er interesseret i om noget gælder eller ej. I (36) vil man således typisk have sine tvivl og have brug for en bekræftelse.

(35) Jeg ved godt hvad jeg gor.

(36) Ved du godt hvad du gor?

Godt er til gengæld ikke så vellykket i $h v$-spørgsmål som i (37).

(37) ?? Hvad ved du godt om Reformationen?

I $h v$-spørgsmål er man interesseret $\mathrm{i}$ at få en bestemt oplysning og ikke så meget $\mathrm{i}$ om noget er tilfældet eller ej. Faktisk går man i reglen stiltiende ud fra at det $h v$-spørgsmålet handler om, er sandt. Hvis jeg spørger: Hvor har Louise kabt bus?, tager jeg det for givet at vi er enige om at Louise har købt hus (Horn 1972: 14). Der er således ikke behov for også at fokusere på den positive polaritet. Hvis der alligevel forekommer et godt som i (37), vil man uvægerligt forstå det som et ekko-spørgsmål, altså et spørgsmål hvor man gentager noget modtageren tidligere har sagt, f.eks. fordi man ikke lige fik fat på det hele.

10 Positivt polaritetsfokus udtrykkes typisk med prosodisk tryk på verber eller konjunktioner (Höhle 1992).

(6) Jeg HAR forstået det.

(7) Jeg ved AT bun kommer, men ikke hvornår. 
(38) A: Jeg ved godt at Reformationen fandt sted 11517.

B: Hvad ved du godt om Reformationen?

Det er altså igen et punkt hvor godt adskiller sig fra negationen, som sagtens kan forekomme i hv-spørgsmål.

(39) Hvem har ikeke provet at komme for sent til et tog?

(40) ?? Hvem har godt provet at komme for sent til et tog?

Godt er heller ikke vellykket i imperative sætninger som netop endnu hverken er sande eller falske (de er en opfordring til at gøre noget sandt). Det kan være svært at finde et godt eksempel, for de fleste verber som kan kombineres med godt, danner i forvejen ikke imperativ. Men verber som fortalle og fatte kan danne imperativ, og her kan godt ikke forekomme.

(41) * Fortal godt hvad du ved!

(42) * Så fat det dog godt!

I irreelle ønskesætninger er godt heller ikke så vellykket fordi der ikke er nogen positiv polaritet at fokusere på. Når man ønsker at verden ser anderledes ud end den gør, er det jo netop fordi det man ønsker, ikke er tilfældet. En irreel ønskesætning som (43a) giver kun mening fordi afsenderen netop ikke har forstået hentydningen.

(43) a. Bare jeg dog havde forstået hentydningen!

b. ?? Bare jeg dog godt havde forstået hentydningen!

Med godt understreger man altså at noget virkelig er tilfældet, og det gør man jo så typisk hvis man har en mistanke om at ens samtalepartner ikke rigtig har forstået at det faktisk forholder sig sådan. Det er det der skjuler sig bag Hansen og Heltofts (2011: 1090) beskrivelse af godts betydning som "at ophæve et modsynspunkt" og Jensens (2009: 72) implikatur: someone does not think so. Hvis jeg siger: Jeg forstår det godt, er det fordi jeg har en fornemmelse af at min samtalepartner tænker: Du forstår det ikke. Og når jeg siger: Peter fortalte det godt, er det igen en 
understregning af at jeg faktisk allerede har hørt det (og fra Peter selv), men det lader ikke til at modtageren er klar over det. Man fokuserer kun på at noget er sandt hvis der kan herske tvivl om det (Lenker 2007: 99). Ved at fokusere på positiv polaritet udelukker man den ellers forventede negative version. Og det er præcis sådan fokus-semantik kan beskrives: Fokus betoner at en given proposition er udvalgt blandt en mængde af alternativer (Rooth 1992: 76). Ved at sige Kun Peter kommer udelukker jeg et (sandsynligvis forventeligt) alternativ, nemlig at Louise også kommer. Og når jeg siger at jeg godt har læst kontrakten, udelukker jeg at jeg ikke har læst kontrakten. I Den Danske Ordbog (DDO) (2004) står der for næsten alle eksempler med godt at det bruges for at gøre et udsagn mere "utvetydigt". Man gør noget mere utvetydigt ved at udelukke alternativerne.

Når man med godt fokuserer på at noget er tilfældet, går man som afsender ud fra at en mængde af alternativer allerede er aktiveret i modtagers bevidsthed. Det er med andre ord allerede et spørgsmål som man interesserer sig for. Derfor kan godt ikke forekomme første gang man præsenterer en idé som i (44).

(44) \# ${ }^{11}$ Jeg ved hvad vi kan gore for at skaffe penge til ferien. Vi kan godt salge bilen.

Her kan man ikke bruge godt fordi idéen om eventuelt at sælge bilen endnu ikke er aktiveret. Men modtageren kan så - efter at idéen er kommet på bordet - svare som i (45).

(45) Vi kan godt salge bilen for min skyld.

Det er også grunden til at godt umiddelbart er bedst i sætninger med substantiver $\mathrm{i}$ bestemt form hvor referenten altså er kendt $\mathrm{i}$ forvejen. Eksempel (46a) med bestemt objekt (pigen) er helt uproblematisk, mens eksempel (46b) med ubestemt objekt (en pige) er underlig uden for en

11 Symbolet '\#' betyder at eksemplet er pragmatisk afvigende. Sætningen Vi kan godt salge bilen er isoleret betragtet helt $\mathrm{i}$ orden, men den kan dårligt forekomme $\mathrm{i}$ en sammenhæng som eksempel (44). 
specifik kontekst hvor samtalen åbenbart drejer sig om hvem der kender et eller andet hunkønsvæsen der har boet to år i Vietnam.

(46) a. Jeg kender godt pigen der har boet to àr i Vietnam.

b. ?? Jeg kender godt en pige der har boet to år i Vietnam.

Og godt forekommer meget ofte i konstruktioner hvor to modsætninger sættes op imod hinanden (man forventer ofte et men eller bvorimod ...) (Jensen 2009: 74-75).

(47) De vidste godt, hvorfor de sad der, men ikke helt, hvad de ventede pa.. ${ }^{12}$

Men interessant nok kan godt ikke koordineres med negationen (og her er godt forskellig fra det sammenlignelige nederlandske wel, der godt kan koordineres med negationen, Sudhoff 2012: 125 ff.). Her ser vi igen at godt ikke er et umiddelbart modstykke til negationen.

(48) ??/* Sporgsmålet er om regeringen godt eller ikeke er klar over problemet.

Denne beskrivelse af godts semantik kan ikke umiddelbart forklare at godt typisk forekommer sammen med bestemte verber. Polaritet forekommer ved alle propositioner, men godt som fokusadverbium forekommer i reglen med modalverber der betegner mulighed (kunne, ville, måtte) og ved sanse- og erfaringsverber som fortalle, sige, hore, se, lase, huske (Jensen 2009: 70-71; Hansen og Heltoft 2011: 1090-91). Det forekommer til gengæld ikke ved modalverber der betegner nødvendighed (skulle). Spørgsmålet er om der her er tale om at godt kun kan kombineres med verber med en bestemt betydning (altså semantisk selektion), eller om det er sådan at godt typisk forekommer sammen med nogle bestemte verber uden at det dog udelukker at godt kan forekomme med helt andre verber også (et kollokationelt forhold). Jensen (2009) mener at der er tale om semantisk selektion, sådan at godt forekommer ved verber der betegner "subjective beliefs and emotions" (s. 70), mens man ikke finder godt ved verber som lobe og synge, der er "open to inter-

12 Jyllands-Posten, 31/5 1998 (KorpusDK). 
subjective debate" (s. 71). Der er dog tegn på at godt også anvendes ved verber af sidstnævnte kategori. Det er ikke helt oplagt at fortclle og sige skulle være subjektive verber, og man finder også godt ved verber som spise og prove.

(49) (I en kontekst hvor en bruger kommenterer et blog-indlæg om et restaurantbesøg):

Tillykke! :-) Jeg har godt spist der. Under CPH Restaurant Week. Og var faktisk heller ikeke begejstret ;-) Kodet var bl.a. tort, og så var der alt for koldt. ${ }^{13}$

(50) Larke har godt provet at få lidt ondt $i$ benene, (.... $)^{14}$

Det er således muligt at godt oprindeligt var semantisk begrænset til verber der udtrykker subjektive antagelser og følelser, men det lader til at godts anvendelsesområde bliver udvidet. På den måde er den meget hyppige anvendelse af godt med bestemte verber som modalverber og kognitionsverber ud fra et synkront synspunkt i højere grad et kollokationelt forhold: Det forekommer typisk med nogle bestemte verber, men der er ikke nogen klar semantisk selektion.

Der er dog også tilfælde hvor brugen af fokusadverbiet godt er afsvækket. Her er kombinationen så fast at anvendelsen nærmest må gælde som leksikaliseret. I forbindelse med verbet forstå er godt efterhånden mest af alt disambiguerende mellem læsningen at erfare (51a) og læsningen at have forståelse for (51b). Ved at kunne tanke sig disambiguerer godt mellem en læsning som at forestille sig noget (52a) og at onske sig noget (52b).

(51) a. Jeg forstar at Peter er sur. (Det er kommet mig for øre at ...)

b. Jeg forstair godt at Peter er sur. (Jeg har forståelse for at ...)

(52) a. Jeg kunne tconke mig at han kommer for sent. (Jeg kunne forestille mig at ...)

b. Jeg kunne godt tonke mig at han kommer for sent. (Jeg ønsker mig at ...)

13 http://christinadueholm.dk/2014/10/10/last-night-7/, tilgået 9/1 2018.

14 https://nordjyske.dk/nyheder/skoleboern-traener-til-faelles-loeb/ec6bba97-4ef1-4cbdaeb8-b791f52d3ff6, tilgået 10/1 2018. 
Og ved verberne gide og orke er godt nærmest obligatorisk i fremsættende hovedsætninger (jf. Jensen 1997: 160) mens det kan udelades i relativsætninger (53c) og ja/ nej-spørgsmål (53d). ${ }^{15}$

(53) a. ?? Jeg gider deltage i udflugten.

b. Jeg gider godt deltage $i$ udflugten.

c. Alle der gider deltage $i$ udflugten, skeal skrive sig på listen.

d. Gider du deltage i udflugten?

Ud fra et synkront perspektiv er godt altså ved nogle verber nærmest smeltet sammen med verbet, og det er svært at afgøre hvad godt præcis betyder her. Det gælder også når godt forekommer sammen med ville $\mathrm{i}$ performative talehandlinger, og hvor afsenderen altså præsenterer sit ærinde, her at takke nogen for noget, som et ønske eller en hensigt frem for at gå lige til sagen som i (54b).

(54) a. Jeg vil godt takke formanden for hans store arbejde.

b. Jeg takker formanden for hans store arbejde.

Der lader med andre ord til at være en glidende overgang mellem en brug af godt som polaritetsfokus til en afsvækket brug hvor godt fast optræder med enkelte verber $\mathrm{i}$ bestemte betydninger eller bestemte anvendelser.

\section{BESKRIVELSEN AF GODT I ORDBØGER}

De grundige beskrivelser af fokusadverbiet godt i Jensen (1997, 2000, 2007, 2009) og Hansen og Heltoft (2011) er af relativt nyere dato og har endnu ikke fundet vej til den leksikografiske beskrivelse af godt i nyere mono- og bilingvale ordbøger. Problemet ved beskrivelsen af fokusadverbiet godt er på den ene side at det har idiosynkratiske egenskaber som at det typisk forekommer sammen med et relativt begrænset antal verber (ville, kunne, forstå og vide) og på den måde mest opfører sig som en kollokator "which expresses an aspect of what can be done

15 Hvis godt forekommer i et ja/nej-spørgsmål med verbet gide, forstås det let som et (irriteret) direktiv.

(8) Gider du godt deltage i samtalen? 
with the base" (Cop 1988: 38). På den anden side har man samtidig en fornemmelse af at godt bruges på nogenlunde samme måde ved de enkelte verber, og at man derfor kan beskrive godt isoleret, altså uafhængigt af de verber det typisk forekommer sammen med. Det er altså ikke altid sådan at kollokatoren bliver disambigueret af de enkelte verber, altså at den skifter betydning alt efter hvilket verbum den forekommer sammen med. Det understøttes yderligere af at denne 'abstrakte' betydning opstår når godt står et bestemt sted i sætningen, nemlig i neksusfeltet: før verberne $i$ en ledsætning eller før eventuelle infinitte verber $\mathrm{i}$ en hovedsætning. Så godt opfører sig på én gang idiosynkratisk som del af en kollokation og 'efter bogen' som et adverbium der kan have hele sætningen i sit virkefelt. Denne dobbelthed afspejler sig i de eksisterende beskrivelser i ordbøger og grammatikker.

DDO (2004) er symptomatisk idet kombinationen af idiosynkrasi og generalisering bliver meget tydelig. Artiklen for adverbiet godt er opdelt i ni forskellige betydningsbeskrivelser, hvoraf de første syv angår brugen af godt som selvstændigt adverbielt led. Den første er læsningen "på en god måde", mens seks betydningsbeskrivelser viser godt i kombination med forskellige verber eller grupper af verber (ville, kunne, måtte, gide, turde og erfarings- og sanseverber). Som det er typisk i monolingvale ordbøger, er der altså en selvstændig indgang for kollokatoren med angivelse af enkelte mulige baser (verber) og godts betydning i kombination med disse baser (Cop 1988). Alligevel føler man at man går glip af en generalisering eftersom de enkelte betydningsbeskrivelser ligner hinanden meget. I definitionerne anvendes formuleringer som kredser om at gøre et udsagn mere utvetydigt eller høfligt/personligt.

\footnotetext{
- (...) for at gore et onske mere utvetydigt eller hofligt (under verbet: ville)

- (...) for at gore udsagnet mere utvetydigt eller personligt (under verbet: kunne)

- (...) for at gore en tilladelse mere utvetydig eller hoflig (under verbet: måtte)

- (...) for at gore udtrykket mere utvetydigt eller hofligt (under verbet: turde)
} 
Man får altså en fornemmelse af at de forskellige betydninger kan slås sammen, eller $\mathrm{i}$ hvert fald at de kan udledes af en bestemt egenskab ved godt som kan genfindes i de enkelte anvendelser. På den måde tjener de enkelte kollokationelle baser altså ikke til at disambiguere kollokatoren - der synes at være en fælles betydningsmæssig kerne som ikke helt kommer frem i ordbogsbeskrivelsen, og som ville adskille den 'abstrakte' læsning fra læsningen "på en god måde". Her adskiller DDO sig fra Ordbog over det danske Sprog (ODS) som faktisk har godt i den 'abstrakte' betydning som én selvstændig betydningsvariant som udtryk for "en indrømmelse, mulighed olgn.: skønt det modsatte (paa en vis maade) skulde ell. kunde ventes (efter tilbørlighed, rimelighed, sandsynlighed osv.)." ODS har til gengæld ikke en selvstændig artikel for adverbiet godt, men beskriver godt under adjektivet god.

I Vinterberg og Bodelsens Dansk-Engelsk ordbog (1998) finder man godt med et selvstændigt opslag som adverbium, men den særlige 'abstrakte' anvendelse nævnes ikke som en egentlig selvstændig betydning. Godt behandles som kollokator idet der gives eksempler med godt i kombination med verberne kunne, måtte og forstå - og langt de fleste eksempler er med kunne. Derudover finder man også eksempler med godt under indgangene for de enkelte verber såsom forstå og vide. Interessant nok viser det sig så at godt $\mathrm{i}$ flere tilfælde ikke optræder med nogen egentlig leksikalsk ækvivalent på engelsk. Kun i nogle tilfælde nævnes quite, well og quite well som en mulig oversættelse, og det markeres i reglen som optionelt, som følgende eksempler fra Vinterberg og Bodelsen (1998) viser.

(55) Jeg forstår godt

(56) Jeg kan godt se det

(57) Du kan godt gå nu (tilladelse)

(58) Det må du godt (gore) $\rightarrow \quad$ I (quite) understand; I can well understand

$\rightarrow \quad$ I can see it (quite well)

$\rightarrow$ you may (el. can) go now

$\rightarrow$ you may; By all means, do!

Alt i alt bliver man altså ikke meget klogere på hvad godt egentlig betyder på dansk, og hvornår man kan eller bør anvende et forstærkende quite eller well på engelsk. Faktisk kan man undre sig over at man ved 
verbet vide finder to forskellige oversættelser hvor well er optionelt i den ene og obligatorisk i den anden.

(59) Jeg ved godt at

\section{I know (quite well) that; (mere formelt) I am well aware that;}

Netop fordi det åbenbart er uklart om eller hvornår godt skal oversættes, ville en eksplicitering af godts semantiske bidrag være nyttig for brugeren. Kun på den måde kan brugeren i en konkret sammenhæng træffe et kvalificeret valg.

I Gyldendals Dansk-Tysk Ordbog (2007) er der - som nævnt - ikke meget hjælp at hente. Under opslaget for godt nævnes den 'abstrakte' brug slet ikke (og heller ikke under opslaget for adjektivet god). Og godt nævnes heller ikke under de enkelte baser. Under indgangene for ville, turde, måtte og forstå finder man højst enkelte eksempler med godt som mådesadverbium (bun vil ham det godt). Under artiklen for verbet vide finder man et enkelt eksempel med godt som vist i (60a). Og her kan man se at godt ikke bliver oversat - som det også var tilfældet ved flere af eksemplerne fra engelsk, mens der under kunne er et enkelt eksempel hvor godt oversættes til schon som i (60b).

(60) a. jeg ved det godt ich weiß (es)

b. det kan godt være at ... es mag/kann schon sein, dass ...

Også her savner man altså en eksplicitering af godts semantiske bidrag og forslag til hvordan det kan oversættes, hvis det er ønskeligt i konteksten (altså hvis der tydeligvis er tale om polaritetsfokus). I on-lineudgaven af Gyldendals røde ordbøger finder man flere eksempler med godt i den 'abstrakte' betydning. Det skyldes sandsynligvis at on-lineudgaven finder alle eksempler med godt fra ordbøgerne, altså også fra den tysk-danske ordbog. Problemet er at man som bruger skal kigge sig igennem 247 eksempler med godt under "udtryk og vendinger". Dertil kommer at man får eksempler på godt i alle mulige anvendelser (jf. fodnote 1), og det kræver stor sproglig indsigt at identificere de eksempler hvor godt er brugt i den 'abstrakte' betydning - specielt fordi den abstrakte anvendelse ikke beskrives eksplicit i opslagene for godt. 


\section{HVORDAN GENGIVES GODT PÅ TYSK?}

Eftersom der ikke er så meget at hjælp at hente i Gyldendals DanskTysk Ordbog, vil jeg i det følgende undersøge hvordan godt gengives på tysk i parallelle danske og tyske tekster. Jeg har her anvendt Europarl-korpusset ${ }^{16}$ (Koehn 2005; Tiedemann 2012), som indeholder udskrifter af EU-debatter på de officielle EU-sprog. I Europarl-korpusset er det ikke muligt at se om en tekst er kildetekst, eller om den i sig selv er oversat. Det er med andre ord muligt at både den danske og tyske tekst er oversættelser, eller at enten den danske eller den tyske tekst er en oprindelig kildetekst. Det afgørende i denne sammenhæng er dog at undersøge hvordan de tyske tekster udformes i kontekster hvor der i en dansk tekst forekommer godt - uafhængigt af hvad der er mål- og hvad der er kildetekst. På den måde kan man få et indtryk af hvordan oversættere gengiver kontekster hvor der på dansk forekommer et godt i den 'abstrakte' betydning, altså hvor godt optræder som fokusadverbium.

En søgning på ordformen godt giver i alt over 27000 forekomster i de danske tekster. For at begrænse materialet har jeg udvalgt de første 1000 forekomster af ordet godt. Heraf har jeg frasorteret de forekomster hvor godt enten er et adjektiv eller utvetydigt forekommer som mådesadverbium. Et eksempel på et utvetydigt mådesadverbium er (61) hvor godt optræder i indholdsfeltet (altså efter et infinit verbum). ${ }^{17}$

(61) Dette er den politiske kerne af udfordringen, og jeg mener, at De har identificeret den godt for Parlamentet her $i$ dag. ${ }^{\text {. }}$

Derudover er forekomsterne af godt med præmodifikation (valdig godt) udeladt. Som nævnt er forholdene omkring præmodifikation af fokusadverbiet godt uafklarede, og præmodifikation synes at være leksikalsk idiosynkratisk, altså afhængig af det verbum godt lægger sig til. Jeg har derfor udeladt disse eksempler for at koncentrere mig om forekomster af godt i den 'abstrakte' betydning alene.

Resultatet heraf er at der findes i alt 213 eksempler med (umodifice-

16 Jeg har anvendt version v7 fra 2012: http://statmt.org/europarl/. Korpus og søgemaskine findes under følgende URL: http://opus.nlpl.eu/index.php, sidst tilgået 12/12 2017.

17 Alle eksempler med højtstillet ${ }^{\mathrm{E}}$ stammer fra Europarl-korpusset (se fodnote 16). 
ret) godt i brug som polaritetsfokus. En sammenligning med de parallelle tyske tekster giver resultaterne i tabel 1.

TABEL 1

\begin{tabular}{|c|c|c|c|}
\hline Ækvivalent & Antal & Dansk eksempel & Tysk eksempel \\
\hline Ingen & 81 & Det ved vi godt. ${ }^{\mathrm{E}}$ & Wir wissen das. ${ }^{\mathrm{E}}$ \\
\hline Leksikaliseret & 36 & $\begin{array}{l}\text { Men jeg kunne godt tænke } \\
\text { mig nogle mere konkrete } \\
\text { forslag. }{ }^{\mathrm{E}}\end{array}$ & $\begin{array}{l}\text { Zugleich bätte ich mir aber } \\
\text { konkretere Vorschläge ge- } \\
\text { wünscht. }\end{array}$ \\
\hline $\begin{array}{l}\text { Ingen - sekvens } \\
\text { ikke oversat }\end{array}$ & 26 & $\begin{array}{l}\text { Med overbevisning } i \text { stemmen } \\
\text { vil jeg afslutningsvis godt sige, } \\
(\ldots)^{\mathrm{E}}\end{array}$ & $\begin{array}{l}\text { Aus Überzengung sage ich } \\
\text { zum Schluss, ... }\end{array}$ \\
\hline Parafrase $^{18}$ & 6 & Jeg er godt klar over, at $(. . .)^{\mathrm{E}}$ & Ich verkenne nicht, dass $(. . .)^{\mathrm{E}}$ \\
\hline (sehr) wobl & 12 & $\begin{array}{l}\text { Vi ved godt, at den ikee kan } \\
\text { afsluttes inden for disse seks } \\
\text { maneder. }{ }^{\mathrm{E}}\end{array}$ & $\begin{array}{l}\text { Wir wissen sehr wobl, daß } \\
\text { diese in sechs Monaten nicht } \\
\text { abgeschlossen sein werden. }{ }^{\mathrm{E}}\end{array}$ \\
\hline $\begin{array}{l}\text { selbstverständlich / } \\
\text { natürlich }\end{array}$ & 4 & $\begin{array}{l}\text { Jeg ved godt, at det ikeke er } \\
\text { Kommissionens sag, }(. . .)^{\mathrm{E}}\end{array}$ & $\begin{array}{l}\text { Selbstverständlich weiß ich, } \\
\text { dass dies nicht Sache der } \\
\text { Kommission ist }(. . .)^{\mathrm{E}}\end{array}$ \\
\hline Durchaus & 6 & $\begin{array}{l}\text { Hr. formand, ja, jeg kan godt } \\
\text { tage ordet inden fru Auroi, så } \\
\text { bun kan få tid til at komme til } \\
\text { stede i salen. }{ }^{\mathrm{E}}\end{array}$ & $\begin{array}{l}\text { Herr Präsident, ich kann } \\
\text { meinen Vortrag durchaus vor } \\
\text { Frau Auroi halten, damit sie } \\
\text { sich Zeit lassen kann. }{ }^{\mathrm{E}}\end{array}$ \\
\hline $\operatorname{gern}(e)$ & 8 & $\begin{array}{l}\text { Jeg kunne godt tanke mig at } \\
\text { kende Kommissionens mening } \\
\text { om dette punk.t (... })^{\mathrm{E}}\end{array}$ & $\begin{array}{l}\text { Ich würde gern den Stand- } \\
\text { punkt der Kommission } z^{u} \\
\text { diesem Punkt erfahren, }(. . .)^{\mathrm{E}}\end{array}$ \\
\hline doch & 2 & $\begin{array}{l}\text { (...) men vi ved godt, at vi } \\
\text { ifolge traktatens bestemmelser } \\
\text { ikeke har nogen beslutningsbefo- } \\
\text { jelser eller nogen indflydelse pa } \\
\text { lovgivningsforlobet. }{ }^{\mathrm{E}}\end{array}$ & $\begin{array}{l}\text { (...) während wir doch wissen, } \\
\text { dass wir kraft des Vertrages } \\
\text { bei der Beschlussfassung nichts } \\
\text { bewirken können bzw. keinen } \\
\text { Einfluss auf das Ergebnis } \\
\text { des Gesetzgebungsverfahrens } \\
\text { haben. }\end{array}$ \\
\hline
\end{tabular}

18 Parafrase dækker over eksempler hvor der (som vist i tabellen) f.eks. anvendes en negeret sætning på tysk i stedet for en positiv. For at gengive fokussemantikken skulle man her anvende et udtryk for negativt polaritetsfokus på tysk, som f.eks. gar nicht. Under alle omstændigheder siger disse eksempler ikke noget om mulige ækvivalenter for godt. 


\begin{tabular}{|c|c|c|c|}
\hline Ækvivalent & Antal & Dansk eksempel & Tysk eksempel \\
\hline schon & 4 & $\begin{array}{l}\text { Derfor vil jeg alligevel godt } \\
\text { gratulere det ostrigske formand- } \\
\text { skab med dets forhandlingssnil- } \\
\text { de den 17. juli. }{ }^{\mathrm{E}}\end{array}$ & $\begin{array}{l}\text { Deswegen möchte ich zwar } \\
\text { schon der österreichischen Rats- } \\
\text { präsidentschaft für ibr Ver- } \\
\text { bandlungsgeschick an diesem } \\
\text { 17. Juli gratulieren. }{ }^{\mathrm{E}}\end{array}$ \\
\hline auch & 2 & $\begin{array}{l}\text { Jeg husker godt den iranskee } \\
\text { by Bam. }{ }^{\mathrm{E}}\end{array}$ & $\begin{array}{l}\text { Ich erinnere auch an die irani- } \\
\text { sche Stadt Bam. }\end{array}$ \\
\hline $\begin{array}{l}\text { sicher / } \\
\text { sicherlich }\end{array}$ & 2 & $\begin{array}{l}\text { (...) som godt kan forklare, } \\
\text { hvad kemiske våben gor ved ens } \\
\text { lunger. }{ }^{\mathrm{E}}\end{array}$ & $\begin{array}{l}\text { Sie können uns sicher erklären, } \\
\text { was chemische Waffen in der } \\
\text { Lunge anrichten. }{ }^{\mathrm{E}}\end{array}$ \\
\hline $\begin{array}{l}\text { (sebr) gut / } \\
\text { nur allzu gut / } \\
\text { viel zu gut }\end{array}$ & 7 & $\begin{array}{l}\text { Jeg forstär godt Parlamentets } \\
\text { forskellige onsker }(. . .)^{\mathrm{E}}\end{array}$ & $\begin{array}{l}\text { Ich verstehe die einzelnen } \\
\text { Wünsche des Parlaments gut } \\
(\ldots)^{\mathrm{E}}\end{array}$ \\
\hline deutlich & 1 & $\begin{array}{l}\text { Men efter et nojere studium } \\
\text { kan jeg godt se, at traet er } \\
\text { både smukt og også bar bevaret } \\
\text { et gennemgäende tema. }{ }^{\mathrm{E}}\end{array}$ & $\begin{array}{l}\text { Nach eingehenderer Betrach- } \\
\text { tung sehe ich aber deutlich, dass } \\
\text { der Baum nicht nur geschmückt } \\
\text { ist, sondern auch ein durchgän- } \\
\text { giges Thema hat. }{ }^{\mathrm{E}}\end{array}$ \\
\hline zwar & 4 & $\begin{array}{l}\text { (...) og det overrasker mig, } \\
\text { at nogle godt vil informere } \\
\text { forbrugerne, men helst ikeke for } \\
\text { meget. }{ }^{\mathrm{E}}\end{array}$ & $\begin{array}{l}\text { (...) und es verwundert mich, } \\
\text { daß manche den Verbraucher } \\
\text { zwar informieren wollen, aber } \\
\text { am liebsten nicht zu viel. }{ }^{\mathrm{E}}\end{array}$ \\
\hline sebrgenau & 3 & $\begin{array}{l}\text { Vi er også godt klar over } \\
(\ldots)^{\mathrm{E}}\end{array}$ & $\begin{array}{l}\text { Wie wir sehr genau wissen } \\
(\ldots)^{\mathrm{E}}\end{array}$ \\
\hline ja & 2 & Det kan godt vare. ${ }^{\mathrm{E}}$ & Das kann ja sein. ${ }^{\mathrm{E}}$ \\
\hline leicht & 1 & $\begin{array}{l}\text { Man kan godt se ärsagerne } \\
\text { bertil. }{ }^{\mathrm{E}}\end{array}$ & $\begin{array}{l}\text { Die Gründe dafür sind leicht } \\
\text { einzuseben. }{ }^{\mathrm{E}}\end{array}$ \\
\hline $\begin{array}{l}\text { Ikke-parallelle } \\
\text { tekster }\end{array}$ & 6 & $\begin{array}{l}\text { Teksterne er ikke parallelle } \\
\text { og kan derfor ikke sam- } \\
\text { menlignes }\end{array}$ & \\
\hline
\end{tabular}

Af tabellen fremgår at der på tysk faktisk kun forekommer en egentlig leksikalsk ækvivalent til godt i 58 tilfælde, altså i ca. $27 \%$ af tilfældene. Omvendt forekommer der i næsten $73 \%$ af tilfældene ikke nogen direkte leksikalsk ækvivalent til godt på tysk. Vi kan her skelne mellem tre forskellige situationer: 
1. Godt forekommer på dansk som polaritetsfokus, men det gengives ikke eksplicit på tysk. Der er med andre ord ingen leksikalsk ækvivalent til godt.

(62) a. Vi er ikke fuldt ud $i$ stand til at beskrive denne andring, men vi er godt kelar over, at den vil vare dybtgaiende. ${ }^{\mathrm{E}}$

b. Wir sind noch nicht imstande, diese Veränderung in ibrer Komplexität zu erfassen, aber wir wissen, dass sie sehr tiefgreifend sein wird. ${ }^{\mathrm{E}}$

2. Godt forekommer på dansk afsvækket og er nærmest leksikaliseret sammen med det pågældende verbum. Her oversættes den samlede betydning til et ækvivalent verbum på tysk hvor godt således ikke har nogen egentlig ækvivalent. Det er eksempler som godt ville/ möchten, godt kunne lide/gefallen, godt kunne tanke sig/möchten.

(63) a. Jeg kan isar godt lide henvisningen til, at vi er et fribedens og navnlig mangfoldighedens kontinent. ${ }^{\mathrm{E}}$

b. Besonders gefällt mir der Verweis darauf, dass Europa ein Kontinent der Freibeit und der Vielfalt ist. ${ }^{\mathrm{E}}$

3. Godt forekommer som del af en sekvens der ikke gengives på tysk. Der er her typisk tale om en indirekte form for performativ talehandling hvor afsenderen udfører en talehandling som at takke nogen idet han eller hun udtrykker sit ønske eller sin hensigt om at udføre denne talehandling. I eksempel (64) udtrykker afsenderen sin hensigt om at takke for det gode samarbejde og opnår derved netop at takke for det gode samarbejde. Eksemplet er således ækvivalent med jeg takker for det gode samarbejde $i$ de seneste uger. Denne form for performative talehandlinger findes på tysk, men er tilsyneladende ikke så hyppig som på dansk.

(64) a. ... jeg vil godt takke for det gode samarbejde $i$ de seneste uger! ${ }^{\mathrm{E}}$

b. Ich bedanke mich für die gute Zusammenarbeit der letzten Wochen. ${ }^{\mathrm{E}}$

(65) a. Det står vi ved, men jeg vil godt understrege endnu en gang, at vi skal gribe dette nye skeridt fornuftigt an, $(. . .)^{\mathrm{E}}$

b. Aber ich betone nochmals: Lassen Sie uns mit Augenmaß an diesen neuen Schritt herangehen! " $^{\mathrm{E}}$ 
Så kan man jo omvendt spørge: Hvornår forekommer der så egentlig en leksikalsk ækvivalent til godt på tysk? I reglen forekommer der en leksikalsk ækvivalent til godt når der på dansk meget tydeligt er tale om polaritetsfokus, altså understregning af at noget imod forventning er tilfældet. Her er man med andre ord nødt til at kigge nøje på konteksten som i (66) hvor afsenderen imødegår en forventet indvending fra modtageren om at en forhandling ikke kan forventes afsluttet inden et formandsskifte. Polaritetsfokus gengives på tysk her med adverbier som schon, durchaus eller sebr wohl, der af Sudhoff (2012) kategoriseres som højere stil.

(66) a. Vived godt, at den ikke kan afsluttes inden for disse seks maineder, og at opgaven derncest overgär til det franske formandssk.ab (....). ${ }^{\mathrm{E}}$

b. Wir wissen sehr wohl, daß diese in sechs Monaten nicht abgeschlossen sein werden und daß die französische Präsidentschaft die Gespräche fortsetzen wird (... $)^{\mathrm{E}}$

Generelt gælder dog at leksikalsk markering af (positivt) polaritetsfokus forekommer mindre på tysk end på dansk. Sudhoff (2012: 131) bemærker det samme for tysk i sin analyse af det nederlandske wel.

Der lader dog til at være en tendens til at tysk markerer positivt polaritetsfokus når to udsagn stilles op i mod hinanden - altså når et positivt udsagn kontrasteres med et negativt udsagn som i (67)-(69). Her kan godt oversættes durchaus, doch, zwar, schon, sehr wohl eller natürlich.

(67) a. og det overrasker mig, at nogle godt vil informere forbrugerne, men helst ikeke for meget. ${ }^{\mathrm{E}}$

b. und es verwundert mich, daß manche den Verbraucher zwar informieren wollen, aber am liebsten nicht zu viel. ${ }^{\mathrm{E}}$

(68) a. Det betyder, at US As domstole godt kan afsige dodsdomme, nàr blot de ikeke eksekveres, (...) ${ }^{\mathrm{E}}$

b. Mit anderen Worten, die Gerichte der Vereinigten Staaten dürfen sehr wohl die Todesstrafe verhängen, wenn sie sie danach nicht vollziehen, $(. . .)^{\mathrm{E}}$ 
(69) a. Vi behover jo ikeke at vente seks årpå den påtconkte revision, vi kan godt begynde tidligere. ${ }^{\mathrm{E}}$

b. Die vorgesehene Überprüfung braucht ja nicht sechs Jabre lang zu warten, das können wir dann schon früher machen. ${ }^{\mathrm{E}}$

Som egentlig polaritetsfokus - til at tilbagevise en samtalepartners fejlagtige opfattelse af et sagsforhold forekommer typisk (sehr) wohl, durchaus eller schon, hvor sehr wohl går for at være højere stil (Sudhoff 2012). Men igen: Det bruges tilsyneladende mindre end godt på dansk.

(70) a. Amerikanerne kunne godt se faren ved dette, eller det kunne $i$ bvert fald en del af den amerikanske Kongres. ${ }^{\mathrm{E}}$

b. Die Amerikaner oder zumindestens ein Teil des amerikanischen Kongresses sieht durchaus die Gefahr. ${ }^{\mathrm{E}}$

Vi kan opsummere kravene til en beskrivelse af fokusadverbiet godt til tysk i en bilingval ordbog:

- $\quad G o d t$ bruges til polaritetsfokus, dvs. til at understrege at noget er tilfældet.

- Hvis det er vigtigt at betone polaritetsfokus, kan man på tysk som hovedregel anvende durchaus, schon eller (sehr) wohl.

- I reglen forekommer der ingen ækvivalent til godt på tysk. Her må man gå ud fra at konteksten er tilstrækkelig.

- Godt forekommer ofte leksikaliseret i kombination med ville eller kunne på dansk. Her skal der gives oversættelser for de respektive kombinationer: godt kunne lide, godt ville, det kan godt vare.

- Godt forekommer ofte sammen med ville i en performativ talehandling. Her kan man oversætte godt ville til möchten, eller man kan udelade denne del af den performative talehandling. Specielt synes talehandlingen med danken at være usædvanlig med möchten på tysk.

Man kan altså sammenfattende sige at leksikalsk markeret polaritetsfokus tilsyneladende anvendes mere på dansk end på tysk. På tysk skal 
der i højere grad være en speciel grund til at et (positivt) polaritetsfokus markeres leksikalsk. Derudover forekommer denne form for polaritetsfokus ofte afsvækket eller ligefrem leksikaliseret på dansk, som det er tilfældet ved verber som gide og ville.

\section{EN LEKSIKALSK INDGANG FOR GODT I EN DANSK- TYSK ORDBOG}

Det er naturligvis en afvejning hvor meget af den lingvistiske beskrivelse man ønsker at medtage i en leksikografisk beskrivelse af et ord. Det spiller her også en stor rolle hvem målgruppen er for en given ordbog. Jeg har her orienteret mig efter Gyldendals Dansk-Tysk. Ordbog (2007) hvad angår layout og detaljeringsgrad af den leksikalske indgang. Gyldendals Dansk-Tysk Ordbog oplyser ganske vist ikke hvem den intenderede målgruppe er, men jeg antager at det er mere avancerede brugere fra gymnasieskolen og opefter.

Forslaget til en leksikalsk indgang er baseret på at brugeren skal vide hvad godt bruges til på dansk for at kunne tage stilling til om og i givet fald hvordan godt skal oversættes i en konkret sammenhæng. Dernæst skal brugeren oplyses om at der på tysk lader til at være mindre tendens til at udtrykke polaritetsfokus ved konstruktioner hvor vi på dansk bruger godt. Endelig skal det angives at enkelte faste forbindelser med godt kræver særlige oversættelser.

Godt, adv., (til at understrege at noget faktisk er tilfældet, måske imod forventning) schon, durchaus, $\left(\mathrm{H}^{19}\right)$ sehr wohl. Jeg ved det godt ich weiß es schon/sehr wobl, hun har godt fortalt det sie hat es schon erzäblt, jeg kan godt overtage posten ich kann den Posten durchaus übernehmen, jeg har godt hørt det ich habe es schon gebört, jeg kan godt forstå at du gerne vil køre med ich verstehe schon/durchaus/sehr wohl, dass du mitfahren möchtest. Oversættes ofte ikke: jeg ved det godt ich wei $\beta$, jeg så det godt $i c h$ babe es gesehen, vi kan godt klare os uden bil wir kommen obne Auto zurecht. I forbindelse med tilladelse gerne du må godt låne bilen du darfst das Auto gerne leihen.

I faste forbindelser: jeg vil godt have en is ich möchte ein Eis, jeg kan

19 H er forkortelsen for 'højtideligt' i Gyldendals Dansk-Tysk Ordbog. 
godt lide is ich mag Eis, jeg kan godt lide hende ich mag sie/ich habe sie gern, det kan godt være es/das mag sein, jeg kunne godt tænke mig at sove ich würde gern schlafen jeg kunne godt tænke mig en is ich hätte gern ein Eis.

I kombination med ville til at udtrykke at man takker, understreger, opfordrer el.lign.: Jeg vil godt takke formanden ich möchte dem Vorsitzenden danken / ich danke dem Vorsitzenden, vi vil godt opfordre Kommissionen til at ... wir möchten die Kommission dazu auffordern, ... / wir fordern die Kommission dąu auf ..., jeg vil godt understrege endnu en gang ich möchte nochmals betonen / ich betone nochmals.

En separat indgang for godtsom (fokus-)adverbium viser både de regelmæssige og de mere idiosynkratiske egenskaber ved godt, og der kan så henvises til denne indgang $i$ opslagene for de hyppigst forekommende verber med godt, nemlig modalverberne (undtagen skulle) og sanse- og erfaringsverberne vide, se, hore og forstå. Fordelen ved ovenstående indgang er at den giver forslag til oversættelse af godt også i de tilfælde hvor godt forekommer med et atypisk verbum såsom spise.

(71) Jeg har godt spist der. $\rightarrow$ Ich habe da schon gegessen.

\section{KONKLUSION}

Ovenstående diskussion har givet et forslag til hvordan et 'leksikografisk hul' i de dansk-tyske ordbøger kan udfyldes. Udfordringen har været at give en beskrivelse af et ord som dels har både regelmæssige og idiosynkratiske egenskaber, og som samtidig har en pragmatisk brug som ikke i samme omfang findes i målsproget, i dette tilfælde tysk. Man kan altså sige at en ordbog netop også skal gøre opmærksom på at nogle ord ikke behøver eller plejer at blive oversat. Diskussionen har forhåbentlig som sidegevinst vist hvordan resultaterne af den mere teoretiske lingvistik kan nyttiggøres i den leksikografiske beskrivelse af enkeltord, ligesom den har udvidet de eksisterende analyser med nye iagttagelser om godts syntaks og semantik/pragmatik. 


\title{
TAK
}

Jeg vil her gerne takke den anonyme fagfællebedømmer, NyS-redaktionen, Sanni Nimb og Jørg Asmussen for alle gode kommentarer, idéer, henvisninger og rettelser. Jeg er alene ansvarlig for fejl og utilstrækkeligheder.

\author{
Bjarne Ørsnes \\ Department of Management, Society and Communication \\ Copenhagen Business School \\ bo.msc@cbs.dk
}




\section{LITTERATUR}

Boye, K. 2007. Ikke at tro. Mål \& male, 30(3). 17-23.

Christensen, T.K. 2012. Epistemiske sætningsadverbier i dansk talesprog. C. Bache, A. Holsting \& U.K. Nissen (red.), Ny forskning i grammatik 19, 5-28. Institut for Sprog og Kommunikation, Syddansk Universitet.

Cop, M. 1988. The function of collocations in dictionaries. T. Magay \& J. Zigány (red.), Proceedings of the 3rd EURALEX international congress, 35-46. Budapest: Akadémiai Kiadó.

Den Danske Ordbog. 2004. Bind 2. København: Det Danske Sprog- og Litteraturselskab. Gyldendal. https://ordnet.dk/ddo.

Dansk-Tysk Ordbog. 2007. Gyldendal.

Hansen, E. 1970. Sxtningsskema og verbalskema. NyS - Nydanske studier \& almen kommunikationsteori 2. Grammatik, pragmatik, og tekstbeskrivelse. 116-142.

Hansen, E. 2000. Anteponeret adverbial. J. Nørgård-Sørensen et al. (red.), Ny forskning i grammatik 7, 73-86. Odense: Odense Universitetsforlag.

Hansen, E. \& L. Heltoft. 2011. Grammatik over det danske sprog, bind 1-3. København: Det Danske Sprog- og Litteraturselskab.

Höhle, T.N. 1992. Über Verum-Fokus im Deutschen. J. Jacobs (red.), Informationsstruktur und Grammatik, linguistische Berichte Sonderhefte 4, 112-142. Wiesbaden: VS Verlag für Sozialwissenschaften. DOI: 10.1007/978-3-663-12176-3_5.

Horn, L. 1972. On the semantic properties of logical operators in English. Bloomington: Indiana University Linguistics Club.

Jensen, E.S. 1997. Godt og gerne - modalitet og polaritet. P. Widell \& M. Kunøe (red.), Mode om udforskningen af dansk sprog 6, 154-164. Århus: Aarhus Universitet.

Jensen, E.S. 2000. Sætningsadverbialer og topologi med udgangspunkt i de konnektive adverbialer. J. Nørgård-Sørensen et al. (red.), Ny forskning i grammatik 7, 141154. Odense: Syddansk Universitetsforlag.

Jensen, E.S. 2007. Negationer med kompleks semantik i polyfonisk belysning. R. Therkelsen, N.M. Andersen \& H. Nølke (red.). Sproglig polyfoni. Tekster om Bachtin og ScaPoLine, 261-282. Århus: Aarhus Universitetsforlag.

Jensen, E.S. 2009. Context-sensitive changes: the development of the affirmative marker godt 'good' and vel 'well' in Danish. M.-B.M. Hansen \& J. Visconti (red.), Current trends in diachronic semantics and pragmatics, 63-79. Amsterdam: Elsevier.

Koehn, P. 2005. Europarl: A parallel corpus for statistical machine translation, MT Summit 5. 79-86. 
König, E. 1991. The meaning of focus particles. London: Routledge.

Lenker, U. 2007. Soplice, forsoothe, truly - communicative principles and invited inferences in the history of truth-intensifying adverbs in English. S. Fitzmaurice \& I. Taivitsainen (red.), Methods in historical pragmatics, 81-106. Berlin: de Gruyter.

Ordbog over det danske Sprog, https://ordnet.dk/ods.

Pedersen, K.M. 2009. Indre at i danske dialekter. R. Therkelsen \& E.S. Jensen (red.), Dramatikeken i grammatikeken, 321-333. Institut for Kultur og Identitet, Roskilde Universitet.

Romero, M. \& C.H. Han. 2004. On negative yes/no questions. Linguistics and Philosophy 27(5). 609-658. DOI: 10.1023/B:LING.0000033850.15705.94.

Rooth, M. 1992. A theory of focus interpretation. Natural Language Semantics 1(3). 75116. DOI: $10.1007 / \mathrm{BF} 02342617$.

Sudhoff, S. 2012. Negation der Negation - Verumfokus und die niederländische Polaritätspartikel wel. Linguistische Berichte 18. 105-136.

Tiedemann, J. 2012. Parallel data, tools and interfaces in OPUS. Proceedings of the 8 th international conference on language resources and evaluation (LREC'2012), 2214-2218. Istanbul, Tyrkiet.

Vinterberg, H. \& C.A. Bodelsen. 1998. Dansk-engelsk ordbog. Ved V.H. Pedersen. Gyldendal.

Ørsnes, B. 2012. Negating the verum - The syntax and semantics of preposed negation in Danish. Journal of Comparative Germanic Linguistics 15(1). 49-105. DOI: 10.1007/s10828-012-9049-4. 